\title{
ХУДОЖНІ ДОМІНАНТИ СЛОВЕСНОЇ ТВОРЧОСТІ ОЛЕКСАНДРА ОЛЕСЯ
}

У статті мова йде про пікові для стану внутрішньої психологічної зосередженості, індивідуально-художньої самоорганізаиії моменти творчості Олександра Олеся, коли йому відкривалися асочіативно-образні зв 'язки світу, кончепти поетової свідомості. Це породжувало величезні за силою творчі імпульси, під впливом яких творилися непересічні, визначні твори, навіть якщо життєві обставини перешкоджали прачі. Характер художньо-семантичного осмислення багатьох кончептів Олесевої творчості є самобутнім, ио дозволяє визначити новаторство мовно-художнього підходу.

Ключові слова: художні домінанти, художня творчість.

В статье речь идет о пиковых для состояния внутренней психологической сосредоточенности моментах творчества Александра Олеся. Именно в такие моменты ему раскрывались ассочиативно-образные связи мира, концепты сознания поэта. Это порождало большущие творческие импульсы, под влиянием которых создавались грандиозные произведения, даже если жизненные обстоятельства препятствовали роботе. Характер художественно-семантического осмысления многих кончептов творчества писателя является самобытным, а это позволяет определить новаторство языкового и художественного подходов.

Ключевые слова: художественные доминанты, художественное творчество.

The article developed about peak for state of inner psychological concentration of the moment of creativity. The temper belles grasp the idea many concepts of creative writer. The article under consideration is about the peaks of inner state of psychological concentration of creative work by O. Oles'.

Key words: belles' predomin, belles creative.

Мистецьке життя О. Олеся тривало майже півстоліття, якщо вести відлік від його перших поетичних спроб у хліборобській школі до останніх поезій 1944 року. Хоча сам О. Олесь початком творчої біографії вважає 1903 рік, пов'язуючи це зі святом відкриття пам'ятника І. П. Котляревському в Полтаві. Такий підхід підтверджується творчими ювілейними заходами. Так, наприклад, 
1918 року в залі Українського клубу в Києві відбувся вечір з нагоди 15-ї річниці творчої діяльності поета, 1923-го українська еміграція вшанувала в Чехії 20-річчя мистецької біографії поета. Відень завдяки М.С. Грушевському вшанував поета виданням вибраних його творів $з$ передмовою самого академіка. 1943-го відбувся вечір 3 нагоди 40-річного ювілею творчості в Міському театрі на Виноградах у Празі за ініціативи та активної участі Українського Вільного Університету.

Сучасне олесезнавство виокремлює два періоди його творчості. Відомий у Чехії й Словаччині дослідник творчості О. Олеся, співробітник Словацької Академії Наук М. Я. Неврлий зазначає: «B першому він відбиває настрій українського громадянства в часах двох революиій - 1905 і 1917 років, які знаменували добу украӥнського начіонального відродження й завершились утвореннял Украӥнської Народної Республіки (1917-1921), а в другому - переживання кращих синів українського народу, що після падіння молодої украӥнської держави опинились "на ріках вавилонських" - на холодній і непривітній чужині» [Неврлий 1994: 7-8].

В. В. Яременко також поділяє Олесеву творчість на два періоди. Перший - між революціями 1905 і 1917 років, другий - період еміграції з 1919 р. [Яременко 1971: 8]. П. А. Ляшкевич вичленовує такі два періоди: 1) доеміграційний (1893-1919), коли Олесь почав писати вірші під час навчання у хліборобській школі, перші вірші («3 пісень молодості») були надруковані в альманаху «Багаття» (1905); 2) еміграційний [Ляшкевич 2002: 35].

Потужний мистецький поступ О. Олеся розпочався виданням збірки «З журбою радість обнялась» на початку 1907 року в Петербурзі накладом у півтори тисячі примірників. Ця збірка іще не була поетом нумерована. Наступна збірка «Поезії. Книга II» (1909) (попередньо мала назву «Будь мечем моїм!», але внаслідок цензурних утисків назва була змінена й відновлена в другому виданні, видана також у Петербурзі) та третя «Поезії. Книга III» (1911) були відгуком поета на поразку революції 1905-1907 років і сповнені 
сумних мотивів. До третьої книжки увійшли ліричні вірші, поема «Щороку» і драматичні твори «Над Дніпром», «Трагедія серця». У цих збірках спостерігається поступове зростання національної свідомості митця: «Якщо в першій збіриі Олеся <..> більшість його поезій громадянського звучання перебувала ще в руслі загальноросійської визвольної боротьби, то в другій перевагу мають віриі начіонально-визвольної проблематики» [Неврлий 1994: 59].

У доеміграційний період О. Олесь написав і видав ще дві збірки - «Драматичні етюди. Книга IV» (1914) та «Поезії. Книга V》 (1917). П'ята книга поезій складалася з поеми «На зелених горах», написаної 1915 року під враженням перебування на Гуцульщині, а також із поезій інтимної й громадянської лірики. До друку була підготовлена і шоста книга поезій, що зазнала трагічної долі. В одному з часописів навіть було повідомлення про вихід збірки на початку 1919 року. Як зазначає М. Я. Неврлий, шоста книга мала назву «На хвилях» [Неврлий 1994: 74], а М. І. Голубєва, сестра поета, засвідчує, що шоста книжка мала назву «Тобі співаю» й була присвячена українському народові. Ця збірка загинула в січні 1919 року за трагічних обставин, коли О. Олесь, спілкуючись зі своїм близьким другом Костянтином Хороманським, на хвилину відійшов до сусідньої кімнати, і тут стався вибух. «Увійшовши в кімнату, - згадує М. І. Голубєва, - він побачив скривавленого Хороманського і роздерту на шматки шосту книгу свойх, ще не друкованих віршів» [Поет $з$ душею вогняною 1999: 16]. Р. П. Радишевський стверджує, що Костянтин Хороманський «писав музику до його VIзбірки "На хвилях"» [Радишевський 2000: 6].

Чимало своїх поезій Олесь друкував у газетах, журналах, альманахах, часописах, серед яких «Громада», «Гедзь», «Дзвін», «Досвітні вогні», «Друкар», «Життя Поділля», «Засів», «Квітничок», «Літературно-науковий вісник», «Молода Україна», «Народна воля», «Нова рада», «Рада», «Рідний край», «Робітнича газета», «Розвага», «Руслан», «Село», «Сяйво», «Україна», «Українська хата», «ШляХ», «Світова зірниця». Друкував О. Олесь статті й фейлетони 
в київській щоденній газеті «Рада» протягом 1910-1915 років, яку видавав Є. Х. Чикаленко, у київських газетах «Відродження» (редактор П. В. Гаєнко), «Трибуна» (редактор О. Х. Саліковський) за

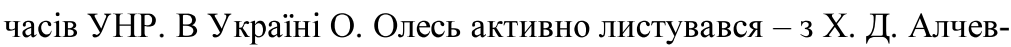
ською, Х. О. Алчевською, Д. В. Антоновичем, М. С. Грушевським, М. К. Заньковецькою, С. О. Єфремовим, А. В. Ніковським, С. Ф. Русовою, П. Я. Стебницьким, Є. Х. Чикаленком, М. Ю. Шаповалом та ін.

Перший період творчості О. Олеся збігається з хвилею піднесення європейської символічної драми (С. Виспянський, Г. Гауптман, Г. Ібсен, М. Метерлінк, А. П. Чехов та ін.), яка захопила й українську драматургію. Не оминула вона й О. Олеся. Порівняно із Західною Європою, де суспільні умови для виникнення модерної поезії були значно зрілішими та де ця поезія, починаючи з «проклятих поетів» - Ш. Бодлера, П. Верлена й А. Рембо - викликала справжню революцію, український модернізм, художньо трансформований символізмом, шукав свої шляхи розвитку у сфері змісту й форми. «Хоча в творчій спадщині Олеся є чимало творів різних жанрів, найсильніше виявив він себе як поет-лірик; його часто порівнюють з Гейне та іншими найвизначнішими ліриками світової літератури. Такого безпосереднього, тонкого лірика українська література після Т. Шевченка - за винятком хіба І. Франка й Лесі Украӥнки - не мала» [Неврлий 1994: 6]. Індивідуально-авторські підходи до образотворення, орієнтація на психологізм, звернення до підсвідомого, філософська глибина поезії виводять постать О. Олеся на обшири вершинних світових досягнень.

Зображення внутрішнього світу людини, митця, ліричного героя - поетична домінанта творчості О. Олеся. У макротексті відображена специфіка образно-асоціативного мовомислення письменника. Вербальні засоби вираження почуттів - журби, печалі, смутку, любові, кохання, радості - розкривають такі риси його поезії, як ніжність та інтимність. У поетичній свідомості митця зринають мрії, породжується марево, накопичуються спогади минулого, часом - якісь невиразні уявлення. Оригінальними є 
засоби індивідуально-мовного втілення світоглядних позицій у поезії митця. О. Олесь усвідомлював себе українським поетом, здебільшого публічно-громадянським репрезентантом української інтелігенції свого часу.

Мовностилістичний малюнок поезії митця вияскравлюється за допомогою розширення структури асоціативно-образних полів традиційних лексико-виражальних засобів, їх лінгвопоетичну концептуалізацію. Художню стилізацію він доводить до тих меж, на яких вона стає умовністю. Усе, що традиційне народництво викреслювало зі змісту поезії, О. Олесь запроваджує з ретельністю колекціонера.

Художньо-мовний світ поет наповнює почуттєвістю й емоційністю. У його мовомисленні доеміграційного періоду «сміявся день», «весь божий день сміявсь», «в сльозах, як в жемчугах, мій сміх», «ваблять, всміхаючись луки», «буде проміння всміхатись нам», «пісні і сміх, і радість скрізь», «трава всміхалась», «усміхи сония», «сміються солов '̈̈», «сонще смісться», «хвиля вже давно сміється», «усмішки блискучого сончя», «сонце сміялось», «сміється ніч», «йому лілея усміхалась». Як зазначає В. П. Петров, Олесевий «вибір образів, барв і ліній зумовлено не прагненням до технічної досконалості або до реалістичності зображення, а тими чи іншими, прямими чи побічними настановами мития» [Петров 1994: 281]. Особливий інтерес становлять погляди О. Олеся на мову і слово та їх роль у становленні й збагаченні художнього стилю української мови першої половини ХХ століття.

Перебуваючи на еміграції, О. Олесь видав сьому книжку «Чужиною» (1919), що була написана й видана у Відні безпосередньо в перший рік закордонного життя та присвячена пам'яті його друга К. І. Хороманського. Ця збірка містить поезії громадянської та інтимної лірики, сповнена суму за рідною землею. Восьма книга О. Олеся - це віршована історія Київської Русі «Княжа Україна», що ії поет написав «за якихось 17-20 днів, перебуваючи в 1920 р. в Марієнбаді на лікуванні» [Олесь 1990: 892]. Але видана вона була 
тільки через десять років у Львові під назвою «Минуле України в піснях. Княжі часи», а в Чехії побачила світ 1940 року (у празькому видавництві «Пробоєм») уже під назвою «Княжа Україна».

Спираючись на архівні матеріали, Р. П. Радишевський зазначає, що разом із сьомою книжкою Олесь спішно готував і восьму: «Збереглася чітко написана рукою поета й титульна сторінка: "Падає листя. Книга VIII. Матері присвячую". Проте й вона не була остаточно скомпонована й видана» [Радишевський 2000: 6].

Дев'ята книжка з назвою «Перезва» була видана О. Олесем у Відні 1921 року (під псевдонімом В. Валентин) і присвячена висвітленню й сатиричній оцінці першої хвилі української еміграції після падіння Української Народної Республіки. На території Радянської України ця збірка побачила світ у 1923 році під назвою «Емігрантська перезва». У Празі 1923 року була видана збірка «Вибір поезій (1903-1923)», до якої увійшли також раніше недруковані вірші попередніх років.

Упродовж багатьох років визрівала десята збірка, написана на чеській землі, - «Поезії. Книга Х», що була видана у Львові 1931 року. Цього ж року знов-таки у Львові вийшла друком одинадцята збірка поета «Кому повім печаль мою...». У ній віддзеркалено ностальгійний душевний стан поета-емігранта, вболівання за долю України, висвітлюється тема гармонії людини і природи. Якщо в десятій збірці переважає інтимна лірика, то в одинадцятій громадянська.

Олесева збірка «Цвіте трояндами...» була видана 1939 року в Празі, вона складається $з$ дванадцяти різних частин і відбиває піднесення духу українського народу після доби Карпатської України. У збройних силах Карпатської Січі брав участь син поета Олег Ольжич. Із цими подіями формувалась надія, що національновизвольна боротьба згодом перенесеться на Галичину, Буковину, а потім і на Наддніпрянщину. Була підготовлена до друку «Книжка без назви» як збірка віршів про Карпатську Україну, що готувалась як XII книга поезій. 
Поет відгукувався на події, які хвилювали свідоме українство та світ. Наприклад, Олесева поема «Терновий вінок» була відгуком на вбивство 25 січня 1938 року в Роттердамі Голови Проводу українських націоналістів Є. М. Коновальця. Драма-трагедія «Земля обітована» була відгуком на трагічну долю сім’ї Крушельницьких, яких було страчено після повернення в Україну.

Наступна книга поезій мала назву «Похмілля». Останньою збіркою О. Олеся можна вважати поезії, які поет записував «В альбом Г. Л.»- записник, подарований Галиною Лащенко. За два 3 половиною місяці (від 29 грудня 1943 р. до 14 березня 1944 р.) у ньому з'явилось близько 120 Олесевих поезій. Частина поезій була надрукована у двотомнику, часописах «Дозвілля», «Дукля», спогадах Г. Р. Лащенко, але зміст записника залишається невідомим широкому загалу читачів.

На еміграції О. Олесь надзвичайно активно публікувався в численних періодичних виданнях, альманахах, календарях, читанках. Його поезії друкувалися в діаспорних часописах «Визволення», «Вільне козацтво», «Вогні», «Воля», «Громада», «Дзвони», «Діло», «Дозвілля», «Наша культура», «Нова свобода», «Нова Україна», «Сміх», «Тризуб», «Український скиталець», газеті «Нова свобода». Друкувався поет у львівському альманасі «Дніпро» (редактор В. I. Дорошенко), журналі «Пчілка», що видавався на Закарпатті за редакцією А. І. Волошина, а також у журналі «Наш рідний край» (редактор О. І. Маркуш). Олесь підтримував на еміграції творчі стосунки 3 часописами «Нові шляхи», «Малі друзі», «Літературнонауковий вісник», «Світ дитини», видавництвами «Книгоспілка», «Неділя», «Червона калина».

Значна частина Олесевої творчої спадщини, ще й досі повністю не оприлюднена, зберігається в таких державних архівосховищах: Інституті рукописів Національної бібліотеки України імені В. І. Вернадського НАН України, Центральному державному архіві вищих органів влади та управління України, відділі рукописних фондів та текстології Інституту літератури імені Т. Г. Шевченка 
НАН України, Львівській науковій бібліотеці імені В. С. Стефаника. Архів О. Олеся в бібліотеці імені В. Вернадського нараховує понад 3 тисячі одиниць зберігання й містить окремі фрагменти збірок «Хвиля», «Друга хвиля», «Чотири доби», «На хвилях».

До двохтомника, упорядкованого Р. П. Радишевським, увійшло близько 600 неопублікованих віршів. Близько 300 поезій, що не увійшли до еміграційних збірок, зберігаються в архіві О. Олеся. У приватних архівах знаходяться його численні автографи. Частина Олесевого архіву взагалі не збереглася. За спогадами Назара Гнатюка, неопубліковані твори Олеся «загинули в травні 1945 по дорозі з Праги до Карлових Варів. Загинула, як кажуть, ціла валіза nanерів» [Поет з душею вогняною 1999: 97].

Окреме місце в Олесевій творчості еміграційного періоду посідає сатира. У Відні поет друкував сатиричні вірші в журналі «Сміх» (1919) та в щотижневому виданні «Воля» (1919-1921). Його сатиру активно друкував місячник «Тризуб», що видавався в Парижі. Результатом поетової діяльності в царині сатири стало те, що О. Олесь підготував до друку сатиричні збірки «Маски» та «Похмілля». Його перу належать гумористичні й сатиричні твори «Ревізор з Кам'янця», «Народний суд», лібрето опери «Влада за кордоном», що й досі не дійшли до читача.

У процесі творчості О. Олесь використовував різноманітні псевдоніми, яких нараховується близько 10. Серед них - В. Валентин, Іван Веселий, Клим Середа, Яків Чорноморець, Олександренко [Радишевський 2000: 6].

Олександр Олесь писав посвяти визначним діячам, письменникам, друзям, поезії до визначних дат, активно листувався. Серед його адресатів - М. С. Грушевський, В. В. Винниченко, П. О. Христюк, В. О. Кушнір, А. І. Яковлів, С. Й. Смаль-Стоцький, Ірина Вільде, В. І. Дорошенко, П. М. Скачковський, М. М. Терлецький, Д. І. Дорошенко. Листувався О. Олесь із видавцями В.С. Прокоповичем (журнал «Тризуб»), М. Ю. Обідним, писав листи до В. К. Короліва-Старого, М. Ю. Шаповала, М. М. Галагана, Д. В. Антоновича, 
А. В. Головка, П. В. Зайцева, Б. П. Матюшенка, К. А. Мацієвича, М. Ф. Чечеля, М. І. Шрага, М. К. Вороного та інших. Поета активно підтримували в листах Ю. П. Тищенко-Сірий, В. С. Приходько, В. М. Леонтович, В. О. Лащенко, родини Красковських, Терлецьких, Лисянських. Листувався О. Олесь також і зі своїми шанувальниками. Прикладом такого спілкування можуть бути Олесеві листи до юної гімназистки з Дрездена Віри Селянської, відомої під псевдонімом Віри Вовк [Неврлий 1994: 137].

Крім ліричних творів, О. Олесь написав низку драматичних етюдів, заклавши підвалини української символістської драми, що сприяли інтегруванню національної літератури в загальносвітовий художній процес. В Олесевих драматичних творах найвиразніше відбилися символістські цінності митця. Він написав драматичну поему «Над Дніпром», драматичний етюд «Трагедія серця», що були включені до третьої збірки 1911 року. Четверта книга поета «Драматичні етюди» видана 1914 року. До неї увійшли драматичні етюди «Осінь», «Танець життя», «При світлі ватри», «Тихого вечора», психологічний етюд «На свій шлях», віршований алегоричний етюд «Злотна нитка», присвячений М. В. Лисенку. Олександр Олесь написав також водевіль «По Мюллеру» (1910) та думу-п’єсу «Хвесько-Андибер» (1916), що є новаторською за жанровою специфікою. Створив поет водевілі й шаржі «Черговий концерт», «Забуття», «За гусака», лібрето опери «Кирило Кожум'яка».

На еміграції, у Празі, поет написав одноактну п’єсу «Вилітали орли» (1936), що була надрукована під псевдонімом В. Валентин. Вона носила сатиричний, навіть пародійний характер. Драма на 4 дії «Земля обітована» написана в Чехії 1935-го, а надрукована 1944 року, була відгуком на страту родини А. В. Крушельницького після ії повернення в Україну з еміграції. У 1941 році була написана драма «Ніч на полонині», вперше опублікована у журналі «Дозвілля» 1943 року. Дослідження Р.Я.Пархомика дає підстави стверджувати, що драматургічна спадщина письменника «нараховує близько тридчяти різноманітних за маси- 
табом та художньою вартістю драматичних творів» [Пархомик 1993: 2].

Чимало драматичних творів О. Олеся не були надруковані за життя, а лише 1990 року були включені Р. П. Радишевським до другого тому видання творів. До нього увійшли п'єси «Хам» (1910), «Художники» (1910), «Меценати і богема» (1910), шарж «Патріот» (1911), «Місячна пісня» (1914), водевіль «Морока», етюди «Юність», «На курорті», «Буржуа» (1917). В архіві поета зберігаються незавершені драматичні твори «Герой», «В замку», «Легенда», «Черговий концерт». Працював О. Олесь також над лібрето для опер і оперет - «Скульптор», «В поштовій конторі», «Український цепелін», «Маскарад», «На курорті», «Ательє художника», над сценарієм фільму «Мазепа».

Стали відомі з еміграційного архіву О. Олеся драматичні твори «Шиночок на передмісті» (п’єсу було підготовлено до друку), «Сватання пана Доробкевича», «Влада за кордоном», «Молоді», «Письменники». Митець написав драматизовану поему «Ніч на полонині», драматичні етюди «Фінал», «Темний ліс», другу частину «Перезви» під назвою «Маски». Майже завершеними можна вважати драми «Герой», «В замку», «На руїнах», «В зеленому лісі», «Легенда».

Зберігаються в архіві Олеся незавершені драматичні твори різних років, лібрето для опер і оперет «Товариство воскресіння Лазаря», «Флорентійська трагедія», «Коварство і любов» та ін. Працював поет і над п’єсою «Останній терпець» про часи ліквідації Запорозької Січі у XVIII ст. та над драмою «Забуття», над інсценізацією «Гайдамаків» Т. Г. Шевченка, перекладом російською мовою та драматичною обробкою «Intermezzo» М. М. Коцюбинського.

Драматичні твори О. Олеся мали певну сценічну інтерпретацію. На сцені «Молодого театру» Лесь Курбас поряд зі світовою класикою інтерпретував й Олесеві етюди. Театрами до постановок були прийняті драматичні твори «По дорозі в Казку» та «Над Дніпром». 
Працював письменник і в прозових жанрах. М. Я. Неврлий називає його прозу несподіваною для пересічного читача, яка, безсумнівно, «свідчить про його мистещькі нахили та уподобання, про критичний погляд на життя, про своєрідне художнє мислення Олеся» [Неврлий 1994: 117]. Письменником написані оповідання, поезії в прозі, памфлети, фейлетони, акварелі, новели, притчі, етюди, серед яких - «В цю ніч...», «Вони», «Капітон Капітонович», «Королі і люде», «Натхнення», «Оповідання про турка Мустафу та грека Фільку», «Острів любові», «Поговір», «Прощальний обід», «Сон», «Уста ії всміхалися». Окрім цього, О. Олесь також є автором оповідань «На Івана Купала», «Пеклива мати», «Пташка», мініатюри «О ясна панночко!», переспіву легенди «Казбек і Машука», етюду «Інтродукція», оповідань «На панському обіді» та «Ми познайомились зовсім випадково...», поезії в прозі «Не до пісень мені», етюдів «Дід Василь», «Коли заходило сонце», гумористичного оповідання «Омелько». Частину своїх прозових творів О. Олесь хотів передати Б. Д. Грінченкові з проханням підготувати їх до друку. $С$ дані, що в 1922 році О. Олесь розпочав великий автобіографічний роман і написав 160 сторінок, та й досі невідомо, чи той твір завершено.

Плідно писав О. Олесь і для дітей. Так, зокрема «Княжа Україна» писалась на замовлення дитячого журналу «Малі друзі» й була адресована передусім дітям та юнацтву, хоча становить інтерес і для дорослого читача. Дитячою поезією слід уважати й «Алфавіт віршами, написаний для сина», підготовлений у 10-х роках XX століття. Для дітей поет пише вірші «Журавлі», «Каченята», «Метелики», «Над колискою», «Ялинка». Дітям адресовані також поезії «Все навколо зеленіє», «Снігурі», «Гусятник». Писав О. Олесь і колискові вірші, календарну обрядову поезію, серед яких «Веснянка», «Дощик» тощо. Понад 150 віршів, поем, казок написав Олесь для свого сина, але це був поетичний дарунок не тільки синові, а й кожній українській дитині.

У Відні протягом 1924-1925 років поет видає дитячі збірочки «Вовченя», «Іменини», «Поєдинок», «Рак-рибалка», «Ялинка»у 
видавництві «Чайка». Особливістю творів «Бджілка і зозуля», «Боровик», «Курочка й лисичка» $\epsilon$ те, що діалоговий характер подачі матеріалу допомагав перевтілюватися в улюблених героїв. Віршовані казки «Лисичка, Котик і Півник», «Мисливець Хрін», «Грицеві курчата та його пси» написані для лялькових театрів.

На еміграції О. Олесь написав такі твори для дітей, як «Чарівний ключик», «Історія великоднього зайця», що зберігаються у відділі рукописних фондів та текстології Інституту літератури імені Т. Г. Шевченка НАН України. Після смерті поета була надрукована його поема для дітей «Водяничок».

У жанрі дитячої літератури О. Олесь створював власні драматизовані казочки (трилогія «Бабусина пригода», «Бабуся в гостях у Ведмедя», «Ведмідь в гостях у Бабусі», казка «Напровесні»), а також інсценізації українських народних казок («Івасик-Телесик», «Лісовий цар Ох», «Микита Кожум'яка», «Солом'яний бичок»). Якщо драматичні інтерпретації поет здебільшого зробив в Україні, то казки були написані переважно в еміграційний період творчості.

О. Олесь відомий як перекладач творів світової класики українською мовою. Письменник займався перекладами з російської, білоруської, грузинської, сербської, болгарської, англійської, німецької мов. Постановка на сцені Українського театру в Києві «Вишневого саду» А. П. Чехова стала можливою завдяки перекладу О. Олеся. Американський національний епос «Пісня про Гайавату», написаний Г. У. Лонгфелло на основі індіанських легенд, був перекладений митцем і виданий українською мовою 1912 року. Цей переклад він здійснив 3 російського варіанту I. О. Буніна, який у свою чергу послуговувався французьким перекладом. Твори самого художника слова перекладені й надруковані в «Антологии украинской поэзии в русских переводах» (1924), німецькою мовою була перекладена Олесева п'єса «Хвесько Андибер» у 30-х роках XX ст.

Переклав О. Олесь також казки для дітей Вільгельма Гауфа «Маленький Мук», «Карлик-довгоносик», «Пригоди з Саїдом» (1911), «Казку про Каліфа-лелеку», «Фатьму-невольницю», «Як 
Лабакан переодягся принцом...» (1913). 1911 року поет переклав і видав друком «Арабські казки» - «Рибалка і заворожене царство», «Подорожі Синдбада-морехода». Письменникові також належить переклад українською мовою казки «Лампа Аладдіна» 3 «Тисячі та однієї ночі», що вперше опублікована 1990 року у двотомнику, укладеному Р. П. Радишевським.

Активно поет переймався і редакторською діяльністю. 1912 року він редагує найпопулярніший журнал того часу «Літературнонауковий вісник». Олександр Олесь був одним із засновників журналу «Українська хата», що почав виходити 1909 року. Ю. П. Сiрий згадує, як «виник журнал молодих під назвою "Українська хата". Матеріальні труднощі видання першого числа "Української хати" полагодили ми так: на пропозичію О. Олеся склалися по "n'ятіриі". Як на наш бюджет, че були чималі гроші» [Поет з душею вогняною 1999: 30]. На його сторінках протягом 1909-1910 pp. поет друкував свої вірші.

У 1919 році письменник працював літературним редактором газети «Трибуна». У Відні вийшло чотири номери сатиричного журналу «Сміх», який він редагував під псевдонімом В. Валентин, редагував суспільно-політичний журнал «На переломі».

Перебуваючи на еміграції, письменник вів активну громадську діяльність. У Відні він був головою Спілки українських письменників та журналістів, заснованої 1919 року за ініціативи та активної участі О. Олеся. Поет став ініціатором створення такої потужної наукової установи, як Український Вільний Університет, що його пізніше було перенесено до Праги. Як засвідчують архівні документи, у другій половині 1920 року у Відні були відкриті курси 3 історії, літературознавства, права і мистецтвознавства для молоді за активної участі Союзу українських журналістів і письменників на чолі з О. Олесем та В. Кушніром, Товариства прихильників освіти С. С. Дністрянського, керівника Українського соціологічного інституту М. С. Грушевського [ДАОВУ. - Ф. 3859]. У січні 1921 року на базі цих курсів почалося створення Українського Вільного Універ- 
ситету. О. Олесь навіть дав у заставу наклад своєї книжки, унаслідок чого університет отримав позику на суму 100 тис. австрійських крон [ДАОВУ. - Ф. 3859]. У 1931 році, коли Український Вільний Університет уже працював у Празі, Олесеві одному з перших було присвоєне звання почесного доктора філософії (honoris causa).

У 1921-1922 роках О. Олесь брав участь в організації допомоги голодуючим та Україні, про що він згадував: «Я зараз працюю над організачією допомоги голодуючим на Украйні, паралельно і в контакті з інтернаціональними організаціями. Вчора мене обрали в комітет...» [Р НУНБ імені В. І. Вернадського НАН України]. Н. Суровцова розповідала про діяльність цього товариства: «Отодi у Відні засноване допомогове Товариство "Голодаючим України"... До чього периого Комітету ввійили ми з Олесем, Іван Косак, Олександр Полюга та Микола Чечель. Згодом його очолив Михайло Сергійович Грушевський, в допомоговій акиї взяли участь як україниі, так і ряд інтернаціональних організачій, $і$ на адресу Київської Академії наук було надіслано самих харчів на суму понад десять тисяч доларів та зібрану одежу. Немов трохи легше стало на душі від того, що ми щось робимо, але пригноблений настрій все одно тяжів над Олесем, $і$ че відбивалося на його поезіях, з яких випромінюється стільки тої печалі, туги, любові, що крається серие, коли їх читаєш...» [Поет з душею вогняною 1999: 66]. Поет особисто надавав грошову допомогу трудовій школі у Святошині, про що зазначено в одному з листів, який зберігається в архіві [Адаменко 1963: 28]. Отже, діяльність О. Олеся була багатоаспектною і безпосередньо спрямованою на збереження і розвиток українського світу, його історії, культури, літератури і рідної мови, а творча постать письменника посідає в історії української літератури належне місце. Він - природжений поет, який побудував власний світ слова і почувань. Митець художньо досконалих поезій, О. Олесь відтворив трагічні злами і потрясіння в історії своєї Батьківщини у XX столітті, оспівав ідеали добра, свободи, любові, розкрив глибини внутрішнього світу людини. «У першій половині 
ХХст. він був королем украӥнської поезії і вже давно вважається класиком української літератури» [Неврлий 1994: 6]. Історичне минуле, сучасність та уявлюване (ідеальне) майбутнє поет бачив i сприймав в одній мовомисленнєвій площині, відчував між ними нерозривний зв'язок, що підтверджується ідейним пафосом його творів. Простежується розуміння універсальної взаємодії різних форм і виявів буття: художній простір в Олесевому поетичному мовомисленні об'єднує світ природи, суспільну дійсність і внутрішній світ людини (ліричного суб'єкта); час абстрагується до понять вічності.

Українська художня мовотворчість початку XX століття, переборюючи народництво 3 його досить утилітарним розумінням мистецтва, дозріла до символізму, сприятливим підгрунтям для якого стала досить-таки романтична українська ментальність. Перша, модерністична, фаза цього символізму виявилася, на думку М. Я. Неврлого, невиразною, неповноцінною. Учений визначає іiі як пресимволізм, до якого належать О. Олесь, Микола Вороний, Григорій Чупринка [Неврлий 1994: 10]. Специфіка ідейно-художнього мовомислення літературної епохи початку XX століття значною мірою зумовлювалася тим, то на зміну реалізмові класичного типу приходили нові мовно-художні явища, природу яких слід шукати в ірраціонально-чуттєвому способі осмислення дійсності й самого призначення словесного мистецтва.

Український модернізм був реакцією на народницьку літературу XIX ст., яка зосередилася на селянській проблематиці та постійному вболіванні над гіркою долею народу, але гомогенно весь український народ не був лише селянською масою. Були в ньому й інші соціальні верстви - робітники, інтелігенція, торгівці. «Європеїзаторська місія модернізму в Украӥні, як і в інших слов 'янських країнах, полягала не тільки в пошуках нових художніх засобів, а й y задоволенні естетичних смаків людини міста» [Неврлий 1994: 10]. Міський читач початку ХХ ст. не був уже задоволеним просвітянсько-народницькою літературою з ії вузьким колом інтересів. 
Він жадібно чекав на твори, у яких би висвітлювались великі проблеми та гострі соціальні й моральні протиріччя сучасності.

Першими виявами модернізму в Україні стали поетичні збірки П. С. Карманського («3 теки самовбивці», 1899), В. М. Пачовського («Розсипані перли», 1901), Б. С. Лепкого («Стрічки», 1901), А. Ю. Кримського («Пальмове гілля», 1901). Теоретиком молодої «модерної» української літератури був талановитий поет, перекладач М. К. Вороний (1871-1940), який 1901 р. надрукував відозву до українських письменників із закликом «хоч трохи наблизитись до нових течій і напрямів сучасних європейських літератур». Ця відозва була своєрідною програмою редагованого ним альманаху «3-над хмар і $з$ долин» (1903). За ним в українське красне письменство прийшли Олександр Олесь (1878-1944), Микола Філянський (1873-1938), Григорій Чупринка (1879-1919). Усі вони поєднали український модернізм 3 «домашньою» поетичною традицією, зокрема з традицією галицької «Молодої музи» (П. С. Карманський, В. М. Пачовський, Б. С. Лепкий та ін.). Перші урбаністичні мотиви модерністів - це оспівування широких площ, бульварів і парків, театрів і кав'ярень та різних принад великого міста. Але українським модерністам саме великого європейського міста й бракувало. Києву й Харкову тих часів вельми далеко було до Парижа й Берліна. «Інша соціальна основа в Україні зумовила й інший характер символізму, який був провідним стилем епохи та який сприйняли українські поети або з першоджерел, тобто з Франції, Німеччини, Італії, або, найчастіше, через посередництво польської, російської, інколи й чеської літератури» [Неврлий 1994: 10]. Якщо ж вести мову про мовно-художні зв'язки української літератури із західноєвропейською, то вони існували віддавна. 3 визначних українських письменників треба згадати насамперед П. О. Куліша, який своєю культурницькою місією вважав ознайомлення земляків із творами Шекспіра, Байрона, Гейне та ін. Твори світової літератури впродовж усього свого творчого життя перекладали І. Я. Франко, Леся Українка, В. І. Самійленко. Франкове «Зів'яле листя» (1896) було 
увертюрою до української модерної поезії. У драматургії одним із аналогічних явищ доцільно вважати «Лісову пісню» (1911) Лесі Українки. У прозі це були імпресіоністичні етюди й новели М. М. Коцюбинського.

Піковими для стану внутрішньої психологічної зосередженості, індивідуально-художньої самоорганізації були саме ті моменти творчості, коли Олесеві відкривалися асоціативно-образні зв'язки світу, концепти поетової свідомості. Це породжувало величезні за силою творчі імпульси, під впливом яких творилися непересічні, визначні твори, навіть якщо життєві обставини перешкоджали праці. Мовно-художній світ О. Олеся відкритий як у бік макрокосму, так і в напрямі мікрокосму, глибина і всеохопність протиріч яких знайшли відображення в його творчості. Характер художньо-семантичного осмислення багатьох концептів Олесевої творчості є самобутнім, що дозволяє визначити новаторство мовнохудожнього підходу. Ця оригінальність полягає в утвердженні ідей Всесвіту і людини як відкритих систем, релятивності світобудови, примату духовного начала над матеріальним, високої змістовності людського життя та боротьби як його неодмінної умови. У цих аспектах О. Олесь типологічно близький до теоретичних засад мистецтва авангарду.

\section{БІБЛІОГРАФІЯ}

Адаменко 1963 - Адаменко А. Г. Архів Олександра Олеся (Кандиби) / А. Г. Адаменко // Збірник оглядів фондів відділу рукописів. - К. : Видавництво АН УРСР, 1963. - C. 19-28.

Ляшкевич 2002 - Ляшкевич П. Муза любові й печалі / П. Ляшкевич // Усе для шкколи. Українська література. 10 клас. - Вип. 5. - 2002. - С. 32-42.

Неврлий 1994 - Неврлий М. Олександр Олесь. Життя і творчість / Асоціація україністів Словаччини / Мікулаш Неврлий. - К. : Дніпро, 1994. - 173 с.

Пархомик 1993 - Пархомик Р. Я. Драматургія Олександра Олеся. Питання модернізації : автореф. дис. ... канд. філол. наук : 10.01.02. / Р. Я. Пархомик ; Львівський державний університет імені І. Я. Франка. - Львів, 1993. - 17 с.

Петров 1994 - Петров В. Проблема Олеся / Віктор Петров // Українське слово : Хрестоматія української літератури та літературної критики XX ст. : у 3 кн. Кн. 1. - К. : Рось, 1994. - C. 275-285.

Поет 3 душею вогняною 1999 - Поет з душею вогняною. Олександр Олесь у спогадах, листах і матеріалах / упоряд., передм. та прим. І. М. Лисенка. - К. : Дніпро, 1999. 
Олесь 1990 - Олесь О. Твори : в 2 т. / упоряд., авт. передм. та приміт. Р. П. Радишевський. - К., Дніпро, 1990. - Т. 1 : Поетичні твори. Лірика. Проза. Поза збірками. 3 неопублікованого. Сатира. - 959 с.

Радишевський 2000 - Радишевський Р. П. Феномен Олександра Олеся / Р. П. Радишевський // Літературна Україна. - 2000. - 9 березня. - С. 6.

Яременко 1971 - Яременко В. Вогненна журба поета / В. В. Яременко // Олесь О. Твори. -К. : Молодь, 1971. - С. 5-28.

Р НУНБ імені В. І. Вернадського НАН України. - Ф. ХV, од. зб. 1474.

ДАОВУ. - Ф. 3859. оп. 1., стор. 134, арк. 136.

ДАОВУ. - Ф. 3859. оп. 1., стор. 139, арк. 37. 